\title{
Legalitas Peremponang atau Muhabet sebagai Organisasi Kemasyarakatan
}

\author{
Reny Heronia Nendissa \\ Fakultas Hukum Universitas Pattimura, Ambon, Indonesia \\ E-mail: yreenn@yahoo.com
}

\begin{abstract}
This writing aims to determine Peremponang or Muhabet or with other names can be categorized as community organizations based on Law Number 7/2013 as amended by Perpu No. 2/2017 because there are still many Peremponang or Muhabet or with other names in Ambon City and Maluku Province which have not been registered as a social organization. This writing uses normative juridical research type with the statute approach and conceptual approach. The results of the study explained that Peremponang or Muhabet or by other names had in fact been there even hundreds of years ago but had not been legalized and registered as mass organizations based on statutory regulations. Suggestions from this writing are. the government must make an inventory of the existence of women or muhabet or with other names in Ambon City and Maluku Province in general and advise to register so that it is not considered illegal other than that the rights and obligations of Ormas can be carried out properly especially the government's responsibility to empower Ormas, so that community welfare can be realized through women or muhabet or with other names.
\end{abstract}

Keywords: Legality; Muhabet; Community Organization.

\section{A. PENDAHULUAN}

Pasal 28 Undang-Undang Dasar Negara Republik Indonesia Tahun 1945, selanjutnya disingkat UUD NRI Tahun 1945 mengatur bahwa kemerdekaan berserikat dan berkumpul mengeluarkan pikiran dengan lisan dan tulisan dan sebagainya ditetapkan dnegan undang - undang. Pasal 28C ayat (2) UUD NRI Tahun 1945 mengatur bahwa setiap orang berhak untuk memajukan dirinya dalam memperjuangkan haknya secara kolektif untuk membangun masyarakat, bangsa dan negaranya. Selanjutnya, Pasal 28E ayat (3) mengatur pula bahwa setiap orang berhak atas kebebasan berserikat, berkumpul, dan mengeluarkan pendapat. Namun pasal 28J ayat (2) memberikan batasan sebagai berikut bahwa dalam menjalankan hak dan kebebasannya, setiap orang wajib tunduk kepada pembatasan yang ditetapkan dengan undang-undang dengan maksud semata-mata untuk menjamin pengakuan serta penghormatan atas hak dan kebebasan orang lain dan untuk memenuhi tuntutan yang adil sesuai dengan pertimbangan moral, nilai-nilai agama, kemanan, dan ketertiban umum dalam suatu masyarakat demokratis. 
Pasal 28 UUD NRI Tahun 1945 secara konstitusional memberikan jaminan kepada masyarakat untuk berpartisipasi dalam seluruh aspek pembangunan sebagai perwujudan sebuah negara demokrasi. Peran serta atau partisipasi masyarakat menjadi bagian penting terhadap pelaksanaan tugas - tugas pemerintah sekaligus sebagai fungsi kontrol juga mewujudkan legitimasi pemerinatahan yang berdaulat.

Partisipasi masyarakat menurut Isbandi adalah keikutsertaan masyarakat dalam proses pengidentifikasian masalah dan potensi yang ada di masyarakat, pemilihan dan pengambilan keputusan tentang alternatif solusi untuk menangani masalah, pelaksanaan upaya mengatasi masalah, dan keterlibatan masyarakat dalam proses mengevaluasi perubahan yang terjadi. ${ }^{1}$

Menurut Ach. Wazir Ws., et al., partisipasi bisa diartikan sebagai keterlibatan seseorang secara sadar ke dalam interaksi sosial dalam situasi tertentu. Dengan pengertian itu, seseorang bisa berpartisipasi bila ia menemukan dirinya dengan atau dalam kelompok, melalui berbagai proses berbagi dengan orang lain dalam hal nilai, tradisi, perasaan, kesetiaan, kepatuhan dan tanggungjawab bersama. ${ }^{2}$

Pasal 1 ayat (1) Undang - Undang Nomor 17 Tahun 2013 tentang Organisasi Kemasyarakatan, selanjutnya ditulis UU No.17/2013, mendefenisikan Organisasi Kemasyarakatan yang selanjutnya ditulis Ormas adalah organisasi yang didirikan dan dibentuk oleh masyarakat secara sukarela berdasarkan kesamaan aspirasi, kehendak, kebutuhan, kepentingan, kegiatan, dan tujuan untuk berpartisipasi dalam pembangunan demi tercapainya tujuan Negara Kesatuan Republik Indonesia yang berdasarkan Pancasila

Ormas bertujuan untuk: a. meningkatkan partisipasi dan keberdayaan masyarakat; b. memberikan pelayanan kepada masyarakat; c. menjaga nilai agama dan kepercayaan terhadap Tuhan Yang Maha Esa; d. melestarikan dan memelihara norma, nilai, moral, etika, dan budaya yang hidup dalam masyarakat; e. melestarikan sumber daya alam dan lingkungan hidup; f. mengembangkan kesetiakawanan sosial, gotong royong, dan toleransi dalam kehidupan bermasyarakat; g. menjaga, memelihara, dan memperkuat persatuan dan kesatuan bangsa; dan h. mewujudkan tujuan negara.

Pasal 6 UU No.17/2013 mengatur bahwa Ormas berfungsi sebagai sarana: a. penyalur kegiatan sesuai dengan kepentingan anggota dan/atau tujuan organisasi; $b$. pembinaan dan pengembangan anggota untuk mewujudkan tujuan organisasi; c. penyalur aspirasi masyarakat; d. pemberdayaan masyarakat; e. pemenuhan pelayanan sosial; $\mathrm{f}$. partisipasi masyarakat untuk memelihara, menjaga, dan memperkuat persatuan dan kesatuan bangsa; dan/atau g. pemelihara dan pelestari norma, nilai, dan etika dalam kehidupan bermasyarakat, berbangsa, dan bernegara.

Peremponang atau Muhabet atau nama lain yang dalam perkembangannya disebut juga dengan Organisasi Sosial atau yang disingkat Orsos, memiliki kepengurusan dan pembagian tugas juga sarana prasarana. Peremponang atau Muhabet sudah ada sejak dulu. Beberapa peremponang atau Muhabet atau dengan nama lain tersebar baik di wilayah Kota Ambon maupun Maluku sudah berdiri puluhan bahkan ratusan tahun serta memiliki pengurus, anggota, sarana prasarana, Anggaran Dasar (AD)-Anggaran

1 Adi, Isbandi Rukminto. (2007), Perencanaan Partisipatoris Berbasis Aset Komunitas: dari Pemikiran Menuju Penerapan. Jakarta: FISIP UI Press, h.27.

2 Ach. Wazir Ws., et al., ed., (1999), Panduan Penguatan Menejemen Lembaga Swadaya Masyarakat., Sekretariat Bina Desa dengan dukungan AusAID melalui Indonesia HIV/AIDS and STD Prevention and Care Project., Jakarta, h.29. 
Rumah Tangga (ART) organisasi layaknya sebuah organisasi sosial kemasyarakatan. Hal ini dapat dijelaskan bahwa secara fakta, organisasi ini sudah ada dan beraktivitas berpuluh bahkan beratusan tahun, tetapi secara hukum belum diakui berdasarkan ketentuan peraturan perundang - undangan yang berlaku.

Salah satu contoh adalah Negeri Hutumuri memiliki 6 (enam) peremponang atau Muhabet dan 2 (dua) peremponang atau Muhabet berada di Dusun Toisapu juga 1 (satu) peremponang atau muhabet di Jakarta. Namun, eksistensi peremponang atau Muhabet hanya sekedar melayani dukacita orang meninggal terutama persiapan sampai prosesi pemakaman dan hampir tidak tersentuh dengan program - program pemerintah termasuk bantuan dana-dana hibah maupun urusan sosial kemasyarakatan padahal jika mencermati defenisi Organisasi Kemasyarakatan adalah organisasi yang didirikan dan dibentuk oleh masyarakat secara sukarela berdasarkan kesamaan aspirasi, kehendak, kebutuhan, kepentingan, kegiatan, dan tujuan untuk berpartisipasi dalam pembangunan demi tercapainya tujuan Negara Kesatuan Republik Indonesia yang berdasarkan Pancasila.

Berdasarkan uraian latar belakang penulisan ini, maka masalah yang dikaji adalah apakah Peremponang atau Muhabet dapat dikategorikan sebagai organisasi kemasyarakatan dengan segala hak dan kewajibannya?

\section{B. METODE PENELITIAN}

Menurut Peter Mahmud Marzuki merumuskan penelitian hukum sebagai proses untuk menemukan aturan hukum, prinsip-prinsip hukum, maupun doktrin-doktrin hukum guna menjawab isu hukum yang di hadapi. ${ }^{3}$ Berdasarkan pendapat Peter Mahmud Marzuki, serta substansi pengkajiannya, maka jenis penelitian yang digunakan dalam penulisan ini dikategorikan sebagai penelitian hukum normatif. Penelitian yang di gunakan dalam penelitian ini adalah pendekatan undang-undang (statute approach), dan pendekatan konseptual (conseptual approach).

\section{PEMBAHASAN}

Secara hakiki, organisasi merupakan upaya atau proses terpeliharanya persatuan, dalam kerangka mempertahankan keutuhan organisasi dalam mencapai tujuan organisasinya. Sondang P. Siagian, menerangkan apa itu organisasi dengan melihat dari sisi hakikat organisasi, yaitu bahwa organisasi dapat ditunjau dari tiga sudut pandang, yaitu : ${ }^{4}$

1) Organisasi dipandang sebagai wadah;

2) Organisasi dapat dipandang sebagai proses;

3) Organisasi sebagai kumpulan orang.

Organisasi berasal dari bahasa Yunani, yaitu "Organon" dan istilah Latin, yaitu "Organum" yang berarti : alat, bagian, anggota, atau badan ${ }^{5}$ Menurut Baddudu-Zain, organisasi adalah susunan, aturan atau perkumpulan dari kelompok orang tertentu dengan

\footnotetext{
3 Marzuki, Peter Mahmud. (2004), Penelitian Hukum, Jakarta: Prenada Media Group, h. 156.

4 Siagian, Sondang P. (1980), Filsafat Administrasi, Jakarta: Gunung Agung, 1980, h. 68.

5 Manulang, M. (1983), Dasar-Dasar Manajemen, Jakarta: Ghalia Indonesia, h. 67.
} 
latar dasar ideologi (cita-cita) yang sama. ${ }^{6}$ Lebih lanjut ada tiga ciri dari suatu organisasi, yaitu : ${ }^{7}$

1) Adanya sekelompok orang;

2) Antar hubungan yang terjadi dalam suatu kerjasama yang harmonis;

3) Kerjasama didasarkan atas hak, kewajiban atau tanggung jawab masing-masing orang untuk mencapai tujuan.

Pada era reformasi ini dengan segala kelebihan dan kekurangannya, secara konkret berupaya untuk mencoba menghadapi tantangan dan memenuhi harapan rakyat yang semakin tinggi tuntutannya atas persoalan kemasyarakatan yang bersifat semakin kompleks. Lebih lanjut Jimly Asshiddiqie berpendapat bahwa dengan demikian masalah sosial, ekonomi, dan budaya yang dihadapi semakin kompleks, sehingga kita tidak dapat lagi hanya mengandalkan bentuk-bentuk organisasi pemerintahan yang konvensional untuk mengatasinya. ${ }^{8}$

Menurut M. Billah dan Abdul Hakim G. Nusantara ${ }^{9}$, umumnya Ormas Indonesia mencerminkan kebangkitan kesadaran golongan masyarakat menengah terhadap masalah kemiskinan, ketidak adilan sosial dan masalah hak asasi manusia. Kini, Ormas di Indonesia dapat pula dikatakan sebagai cerminan kesadaran tentang dampak program pembangunan yang dilaksanakan pemerintah serta tindakan yang diambilnya dalam melaksanakan program tersebut.

Pasal 9 UU No.17/2013 mengatur bahwa Ormas didirikan oleh 3 (tiga) orang warga negara Indonesia atau lebih, kecuali Ormas yang berbadan hukum yayasan. Pasal 10 ayat (1) Ormas sebagaimana dimaksud dalam Pasal 9 dapat berbentuk: a. badan hukum; atau b. tidak berbadan hukum. Pasal 10 Ayat (2) mengatur bahwa Ormas sebagaimana dimaksud pada ayat (1) dapat: a. berbasis anggota; atau b. tidak berbasis anggota.

Pasal 11 ayat (1) Ormas berbadan hukum sebagaimana dimaksud dalam Pasal 10 ayat (1) huruf a dapat berbentuk: a. perkumpulan; atau b. yayasan. Pasal 11 ayat (2) Ormas berbadan hukum perkumpulan sebagaimana dimaksud pada ayat (1) huruf a didirikan dengan berbasis anggota. Pasal 11 ayat (3) mengatur bahwa Ormas berbadan hukum yayasan sebagaimana dimaksud pada ayat (1) huruf b didirikan dengan tidak berbasis anggota.

Pasal 12 ayat (1) Badan hukum perkumpulan sebagaimana dimaksud dalam Pasal 11 ayat (1) huruf a didirikan dengan memenuhi persyaratan: a. akta pendirian yang dikeluarkan oleh notaris yang memuat AD dan ART; b. program kerja; c. sumber pendanaan; d. surat keterangan domisili; e. nomor pokok wajib pajak atas nama perkumpulan; dan f. surat pernyataan tidak sedang dalam sengketa kepengurusan atau dalam perkara di pengadilan.Pasal 12 ayat (2) Pengesahan sebagai badan hukum perkumpulan dilakukan oleh menteri yang menyelenggarakan urusan pemerintahan di bidang hukum dan hak asasi manusia. Pasal 12 ayat (3) Pengesahan sebagai badan hukum perkumpulan sebagaimana dimaksud pada ayat (2) dilakukan setelah meminta pertimbangan dari instansi terkait. Ayat (4) ketentuan lebih lanjut mengenai badan hukum perkumpulan sebagaimana dimaksud pada ayat (1), ayat (2), dan ayat (3) diatur dengan undang-undang. Pasal 13 Badan hukum yayasan sebagaimana dimaksud dalam Pasal 11

\footnotetext{
${ }^{6}$ Badudu-Zain. (1994), Kamus Umum Bahasa Indonesia, Jakarta: Pustaka Sinar Harapan, h.967.

7 M. Manulang, Op.Cit h. 68.

8 Asshiddiqie, Jimly. (2006), Perkembangan dan KonsolidasiLembaga Negara Pasca-Reformasi, Jakarta: Konstitusi Press, h.7

9 Prisma No. 4 Tahun 1988, hlm.27
} 
ayat (1) huruf b diatur dan dilaksanakan sesuai dengan ketentuan peraturan perundangundangan.

Peraturan Menteri Dalam Negeri Nomor 57 Tahun 2017 tentang Pendaftaran dan Pengelolaan Sistem Informasi Organisasi, selanjutnya disingkat Permendagri No 57/2017 mengatur bahwa pendaftaran adalah proses pencatatan terhadap Ormas yang tidak berbadan hukum untuk pencatatan dalam administrasi pemerintahan dengan persyaratan tertentu untuk diberikan Surat Keterangan terdaftar, selanjutnya disingkat SKT oleh Pemerintah yang diselenggarakan oleh Menteri.

Tata cara pendaftaran sebagaimana diatur dalam Permendagri No.57/2017 pada Bagian Kesatu Umum. Pasal 9 Permendagri No.57/2017 mengatur Pendaftaran Ormas dilakukan melalui tahapan: a. pengajuan permohonan; b. pemeriksaan kelengkapan dan keabsahan dokumen Pendaftaran; dan c. penerbitan SKT atau penolakan permohonan Pendaftaran.

Tata Cara Pengajuan Permohonan Pasal 10 ayat (1) Pengurus Ormas mengajukan permohonan pendaftaran secara tertulis kepada Menteri melalui unit layanan administrasi Kementerian dengan tembusan kepada gubernur dan bupati/wali kota. Ayat (2) Permohonan pendaftaran sebagaimana dimaksud pada ayat (1) dapat disampaikan melalui gubernur atau bupati/wali kota pada unit layanan administrasi di daerah provinsi atau kabupaten/kota. Ayat (3) Permohonan pendaftaran melalui bupati/wali kota sebagaimana dimaksud pada ayat (2) dengan tembusan kepada Gubernur. Ayat (4) mengatur bahwa Permohonan pendaftaran melalui Gubernur sebagaimana dimaksud pada ayat (2) dengan tembusan kepada bupati/wali kota. Ayat (5) Unit layanan administrasi sebagaimana dimaksud pada ayat (1) di antaranya terdiri dari perwakilan Direktorat Jenderal Politik dan Pemerintahan Umum. Ayat (6) Unit layanan administrasi di daerah provinsi atau daerah kabupaten/kota sebagaimana dimaksud pada ayat (2) di antaranya terdiri dari perwakilan Badan/Kantor Kesatuan Bangsa dan Politik atau sebutan lainnya di daerah provinsi atau daerah kabupaten/kota. Ayat (7) mengatur bahwa dalam hal unit layanan administrasi di daerah provinsi atau daerah kabupaten/kota sebagaimana dimaksud pada ayat (2) belum tersedia, permohonan pendaftaran disampaikan melalui Badan/Kantor Kesatuan Bangsa dan Politik atau sebutan lainnya di daerah provinsi atau daerah kabupaten/kota. Ayat (8) terkait dengan Permohonan pendaftaran sebagaimana dimaksud pada ayat (1) dan ayat (2) diajukan dan ditandatangani oleh pendiri dan pengurus Ormas. Ayat (9) Dalam hal pendiri meninggal dunia atau berhalangan tetap, permohonan pendaftaran Ormas dapat diajukan dan ditandatangani oleh pengurus Ormas.

Pasal 11 ayat (1) Pengajuan permohonan pendaftaran sebagaimana dimaksud dalam Pasal 10, dilakukan dengan melampirkan persyaratan:

a) akta pendirian yang dikeluarkan oleh Notaris yang memuat $\mathrm{AD}$ atau $\mathrm{AD}$ dan ART;

b) program kerja;

c) susunan pengurus;

d) surat keterangan domisili sekretariat Ormas;

e) Nomor Pokok Wajib Pajak atas nama Ormas;

f) surat pernyataan tidak dalam sengketa kepengurusan atau tidak dalam perkara di pengadilan; dan

g) surat pernyataan kesanggupan melaporkan kegiatan.

Pasal 11 ayat (2) Selain persyaratan permohonan pendaftaran sebagaimana dimaksud pada ayat (1), Ormas melampirkan: 
a) formulir isian data Ormas;

b) surat pernyataan tidak berafiliasi secara kelembagaan dengan Partai Politik;

c) surat pernyataan bahwa nama, lambang, bendera, tanda gambar, simbol, atribut, dan cap stempel yang digunakan belum menjadi hak paten dan/atau hak cipta pihak lain serta bukan merupakan milik Pemerintah;

d) rekomendasi dari kementerian yang melaksanakan urusan di bidang agama untuk Ormas yang memiliki kekhususan bidang keagamaan;

e) rekomendasi dari kementerian dan/atau perangkat daerah yang membidangi urusan kebudayaan untuk Ormas yang memiliki kekhususan bidang kepercayaan kepada Tuhan Yang Maha Esa; dan

f) surat pernyataan kesediaan atau persetujuan dari pejabat negara, pejabat pemerintahan, dan/atau tokoh masyarakat yang bersangkutan, yang namanya dicantumkan dalam kepengurusan Ormas.

Pasal 11 ayat (3) mengatur bahwa Surat pernyataan sebagaimana dimaksud pada ayat (2) huruf b dan huruf $\mathrm{c}$ ditandatangani oleh ketua dan sekretaris Ormas atau sebutan pengurus lainnya. Pasal 12 AD dan ART sebagaimana dimaksud dalam Pasal 11 ayat (1) huruf a memuat paling sedikit:

a) nama dan lambang;

b) tempat kedudukan;

c) asas, tujuan, dan fungsi;

d) kepengurusan;

e) hak dan kewajiban anggota;

f) pengelolaan keuangan;

g) mekanisme penyelesaian sengketa dan pengawasan internal; dan

h) pembubaran organisasi.

Pasal 13 ayat (1) Susunan pengurus sebagaimana dimaksud dalam Pasal 11 ayat (1) huruf c paling sedikit terdiri atas: a. ketua atau sebutan lain; b. sekretaris atau sebutan lain; dan c. bendahara atau sebutan lain. (2) Seluruh pengurus sebagaimana dimaksud pada ayat (1) dan anggota Ormas berkewarganegaraan Indonesia. Pasal 14 Kelengkapan dokumen susunan pengurus sebagaimana dimaksud dalam Pasal 11 ayat (1) huruf $\mathrm{c}$ mencakup: a. biodata pengurus organisasi, yaitu ketua, sekretaris dan bendahara atau sebutan lainnya; b. pas foto pengurus organisasi berwarna, ukuran 4 x 6 (empat kali enam), terbaru dalam 3 (tiga) bulan terakhir; c. foto copy Kartu Tanda Penduduk Elektronik pengurus organisasi; dan d. surat keputusan tentang susunan pengurus Ormas secara lengkap yang sah sesuai dengan AD/ART Ormas.

Pasal 15 ayat (1) Surat keterangan domisili sekretariat Ormas sebagaimana dimaksud dalam Pasal 11 ayat (1) huruf d, dikeluarkan oleh lurah/kepala desa setempat atau sebutan lainnya. (2) Surat keterangan domisili sekretariat Ormas sebagaimana dimaksud pada ayat (1) memuat lampiran: a. bukti kepemilikan, atau surat perjanjian kontrak atau ijin pakai dari pemilik/pengelola; dan b. foto kantor atau sekretariat Ormas, tampak depan yang memuat papan nama.

Setelah semua persyaratan pendirian Ormas terpenuhi, maka ormas dapat menggunakan hak dan kewajiban sebagaimaan diatur dalam UU No.17/ 2013. Adapun hak dan kewajiban Ormas diatur pada BAB VI tentang Hak Dan Kewajiban dan lebih tepatnya pada Pasal 20 mengatur bahwa Ormas berhak:

a) mengatur dan mengurus rumah tangga organisasi secara mandiri dan terbuka; 
b) memperoleh hak atas kekayaan intelektual untuk nama dan lambang Ormas sesuai dengan ketentuan peraturan perundang-undangan;

c) memperjuangkan cita-cita dan tujuan organisasi;

d) melaksanakan kegiatan untuk mencapai tujuan organisasi;

e) mendapatkan perlindungan hukum terhadap keberadaan dan kegiatan organisasi; dan

f) melakukan kerja sama dengan Pemerintah, Pemerintah Daerah, swasta, Ormas lain, dan pihak lain dalam rangka pengembangan dan keberlanjutan organisasi.

Pasal 21 Ormas berkewajiban: a. melaksanakan kegiatan sesuai dengan tujuan organisasi; b. menjaga persatuan dan kesatuan bangsa serta keutuhan Negara Kesatuan Republik Indonesia; c. memelihara nilai agama, budaya, moral, etika, dan norma kesusilaan serta memberikan manfaat untuk masyarakat; d. menjaga ketertiban umum dan terciptanya kedamaian dalam masyarakat; e. melakukan pengelolaan keuangan secara transparan dan akuntabel; dan $\mathrm{f}$. berpartisipasi dalam pencapaian tujuan negara.

Ormas yang dibentuk dan keabsahannya diakui oleh pemerintah berdasarkan peraturan perundang -undangan yang berlaku, maka pemerinath juga bertanggungjawab terhadap ormas yang telah dilegalkan melalui kegiatan pemberdayaan. Hal tersebut sebagaimana diatur berdasarkan pengaturan UU No.17/2013 pada BAB XII tentang Pemberdayaan Ormas. Pasal 40 ayat (1) mengatur bahwa Pemerintah dan/atau Pemerintah Daerah melakukan pemberdayaan Ormas untuk meningkatkan kinerja dan menjaga keberlangsungan hidup Ormas. Ayat (2) mengatur pula bahwa dalam melakukan pemberdayaan Ormas sebagaimana dimaksud pada ayat (1), Pemerintah dan/atau Pemerintah Daerah menghormati dan mempertimbangkan aspek sejarah, rekam jejak, peran, dan integritas Ormas dalam kehidupan bermasyarakat, berbangsa, dan bernegara. Ayat (3) terkait pemberdayaan Ormas sebagaimana dimaksud pada ayat (1) dilakukan melalui: a. fasilitasi kebijakan; b. penguatan kapasitas kelembagaan; dan c. peningkatan kualitas sumber daya manusia. Ayat (4) Fasilitasi kebijakan sebagaimana dimaksud pada ayat (3) huruf a berupa peraturan perundang-undangan yang mendukung pemberdayaan Ormas. Ayat (5) Penguatan kapasitas kelembagaan sebagaimana dimaksud pada ayat (3) huruf $b$ dapat berupa: a. penguatan manajemen organisasi; b. penyediaan data dan informasi; c. pengembangan kemitraan; d. dukungan keahlian, program, dan pendampingan; e. penguatan kepemimpinan dan kaderisasi; f. pemberian penghargaan; dan/atau g. penelitian dan pengembangan. Ayat (6) Peningkatan kualitas sumber daya manusia sebagaimana dimaksud pada ayat (3) huruf c dapat berupa: a. pendidikan dan pelatihan; b. pemagangan; dan/atau c. kursus. Ayat (7) Ketentuan lebih lanjut mengenai pemberdayaan Ormas sebagaimana dimaksud pada ayat (1) sampai dengan ayat (6) diatur dalam Peraturan Pemerintah.

Pasal 41 ayat (1) mengatur bahwa dalam hal pemberdayaan, Ormas dapat bekerja sama atau mendapat dukungan dari Ormas lainnya, masyarakat, dan/atau swasta. (2) Kerja sama atau dukungan sebagaimana dimaksud pada ayat (1) dapat berupa pemberian penghargaan, program, bantuan, dan dukungan operasional organisasi.

Paramponang atau peremponang atau juga diistilahkan dengan Muhabet dan sejenisnya dalam sebuah blog miliknya yang bernama kuti kata, Elifas Tomix Maspaitella, menjelaskan bahwa dengan bantuannya temannya, Sumanto al Qurtuby yang juga anggota Jaringan Islam Liberal (JIL) adalah istilah dalam bahasa Arab yang diperkirakan sebagai etimologinya. Istilah tersebut " muhiba" (kata benda, noun) yang berarti = kunjungan. Kata sifatnya (adjective) ialah "hibat", dan keduanya bersumber dari akar kata " $h u b$ " yang berarti cinta, kepedulian, atau orang - orang yang mendermakan 
sesuatu untuk orang yang dia cintai. ${ }^{10}$ Hal ini dapat dikatakan bahwa Muhabet ialah suatu perhimpunan yang terdiri dari anggota masyarakat atas dasar kepedulian sosial, cinta kasih dan bertujuan untuk membantu anggota masyarakat lain yang perlu dibantu, atau yang berada dalam kesusahan/dukacita. ${ }^{11}$ Dahulu ada pula istilah lokal lain mengenai Muhabet yaitu "PARAMPONANG". Penelusuran leksilkal terhadapnya patut dilakukan. Di duga istilah itu adalah bentuk polisemi dalam Melayu Ambon tentang kata 'perhimpunan' dari kosa kata Bahasa Indonesia. Banding saja kebiasaan membahasa orang Ambon yang sering diakhiri akhiran 'ang' -misalnya:perempuan = parampuang. Penjelasannya mengenai akar kata dari bahasa Arab itu menarik dan dapat diterima sebab bahasa Melayu Ambon bertumbuh ketika bahasa Arab telah menjadi sebuah bahasa yang dikenal orang-orang Ambon di zaman Belanda. ${ }^{12}$

Peremponang atau Muhabet atau dengan nama lain, dapat dikategorikan sebagai organisasi kemasyarakatan. Secara fakta, jika dikaitkan dengan pengertian ormas yang adalah organisasi yang didirikan dan dibentuk oleh masyarakat secara sukarela berdasarkan kesamaan aspirasi, kehendak, kebutuhan, kepentingan, kegiatan, dan tujuan untuk berpartisipasi dalam pembangunan, maka Peremponang atau Muhabet terbentuk karena kepedulian terhadap orang dan keluarga yang mengalami duka karena anggota keluarga atau kerabat yang meninggal dunia adalah memiliki kesamaan aspirasi, kehendak,kebutuhan, kepentingan, kegiatan dan tujuan yang mulia. Peremponang atau Muhabet dengan kepengurusan dan anggotanya mengatur jalannya organisasi tersebut dengan tugas - tugas serta peran - peran mulai dari menyiapkan mempersiapkan jenasah, tempat jenasah disemayamkan, tempat duduk untuk para saudara dan kerabat yang melayat sampai kebutuhan konsumsi, persiapan liang lahat atau kuburan sampai selesai acara sesudah pemakaman. Selain itu, ada juga Peremponang atau Muhabet yang bersepakat untuk bergotong royong membantu anggotanya dalam pembangunan rumah tempat tinggal.

Perkembangan dan perjalanan peremponang atau muhabet dari waktu ke waktu mengalami peningkatan yang tidak hanya memperhatikan keadaan dan kebutuhan anggota yang terbatas dalam pelayanan suka duka saja apalagi dengan kewajiban setiap anggota untuk membayar iuran anggota yang nominalnya disesuaikan dengan kondisi anggotanya yang lebih banyak berlatarbelakang pekerjaan sebagai petani, nelayan dan sebagainya, namun lebih dari itu wadah ini dapat melakukan program - program pemberdayaan anggotanya, baik untuk memenuhi kebutuhan secara organisasi maupun kesejahteraan anggotanya. Organisasi ini telah membantu pemerintah dalam melayani dan memfasilitasi kehidupan bersama yang saling peduli satu dengan yang lain dalam mewujudkan masyarakat Indonesia yang Pancasilais.

Secara yuridis, keberadaan Peremponang atau Muhabet yang berada di Kota Ambon juga di Maluku pada umumnya, belum terdaftar secara sah untuk diperhatikan dan menjadi tanggung jawab pemerintah. Belum semua peremponang atau muhabet yang terdaftar sebagai organisasi masyarakat organisasi yang harus mendapat legalisasi dari pemerintah. Hal ini juga disebabkan karena belum banyak peremponang atau muhabet yang belum tahu atau masih mengalami kesulitan untuk mengurusi kelengkapan administrasi sebagai syarat berdirinya sebuah organisasi kemasyarakatan. Hal ini dapat diketahui dari keberadaan peremponang atau muhabet di Negeri Hutumuri yang memiliki 8 (delapan) peremponang atau muhabet di Hutumuri dan Dusun Toisapu sedangkan 1

\footnotetext{
10 http://kutikata.blogspot.com/2011/04/muhabet-dan-makburet.html

11 Ibid

12 Ibid
} 
(satu) peremponang atau muhabet di Jakarta yang dikenal dengan Peremponang Hutumuri di Jakarta atau disingkat PHJ. Dari 9 (Sembilan) jumlah peremponang atau muhabet di Hutumuri yang baru diakui keberadaannya sebagai Ormas adalah Perempoang Hutumuri di Jakarta (PHJ) dan Peremponang atau muhabet Sinar Pengharapan yang baru terdaftar, padahal ada peremponang atau muhabet yang sudah berdiri lebih dari 100 ( seratus) tahun.

\section{PE N U T P}

Berdasarkan uraian pada bagian pembahasan, maka dijelaskan bahwa berdasarkan pengertian serta tata cara pendirian Ormas serta hak dan kewajiban Ormas menurut UU No.17/2013 sebagaimana diatur lebih lanjut dengan Perpu No 2/2017 dan Permendagri No.57/2017, maka secara fakta keberadaan Peremponang atau Muhabet dapat dikategorikan sebagai organisasi kemasyarakatan dengan segala hak dan kewajibannya. Namun, secara yuridis juga fakta yang ada, masih banyak peremponang atau muhabet yang belum terdaftar.

\section{DAFTAR PUSTAKA}

\section{Buku}

[1] Adi, Isbandi Rukminto. (2007), Perencanaan Partisipatoris Berbasis Aset Komunitas: dari Pemikiran Menuju Penerapan. Jakarta: Depok: FISIP UI Press.

[2] Asshiddiqie, Jimly. (2006), Perkembangan dan KonsolidasiLembaga Negara PascaReformasi, Jakarta: Konstitusi Press.

[3] Manulang, M. (1983), Dasar-Dasar Manajemen, Jakarta: Ghalia Indonesia.

[4] Marzuki, Peter Mahmud. (2004), Penelitian Hukum, Jakarta: Prenada Media Group.

[5] Siagian, Sondang P. (1980), Filsafat Administrasi, Jakarta: Gunung Agung.

\section{Jurnal dan Lain-Lain}

[6] Ach. Wazir Ws. (1999), Panduan Penguatan Menejemen Lembaga Swadaya Masyarakat., Sekretariat Bina Desa dengan dukungan AusAID melalui Indonesia HIV/AIDS and STD Prevention and Care Project., Jakarta.

[7] http://kutikata.blogspot.com/2011/04/muhabet-dan-makburet.html. 